\section{Kampen om sykelønnen}

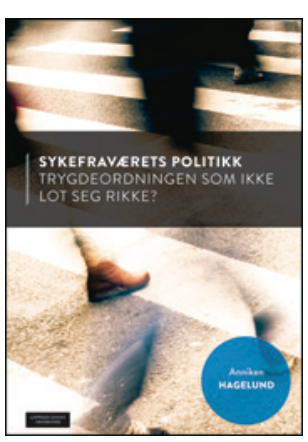

Anniken Hagelund

Sykefraværets politikk

Trygdeordningen som ikke lot seg rikke?

198 s, ill. Oslo: Cappelen Damm Akademisk,

2014. Pris NOK 329

ISBN 978-82-02-40665-3

Anniken Hagelund skriver klart og lettlest om et svært aktuelt tema, den politiske behandlingen av sykelønnen, $100 \%$ sykepenger, fra den ble innført i 1978 og til i dag. Boken er ekstra interessant fordi den ikke bare går gjennom de politiske diskusjonene og beslutningene, men også knytter temaet til statsvitenskapelige teorier om politisk forandring i et velstående parlamentarisk samfunn.

Forfatterens hovedspørsmål er hvorfor ingen har lyktes i å forandre den norske sykelønnen, til tross for at de fleste mektige organer har gått inn for det. Temaet er spennende og belyser dramatisk noen av styringsmekanismene i vårt samfunn. Det mest dramatiske skjedde i desember 2006, da både LO og NHO angrep statsminister Stoltenberg for å ville bryte IA-avtalen.

Alle partier på Stortinget stemte for $100 \%$ sykepenger i 1978 . Utover i 1980-årene forandret denne holdningen seg. Politikerne og næringslivet ble bekymret over de økende utgiftene. Men denne argumentasjonen slo ikke an i opinionen, og politikerne måtte bøye av. I stedet for å redusere utgiftene har myndighetene valgt en annen linje: aktivisering på bred front, fra den store IA-avtalen til mange ulike reformer for å redusere særlig det lange sykefraværet. Hensynet til de sykmeldte selv blir nå fremhevet - det er best for helsa å jobbe, passivisering er farlig.

Forfatteren beskriver og belyser denne utviklingen på en sjarmerende måte uten selv å ta standpunkt. Aktive medborgere er en del av den nye styringsideologien. Vi skal bli i stand til å styre oss selv, mens staten blir mer passiv. Med den franske filosofen Foucault sies det gjerne at staten må skaffe rammer for individenes liv som gjør dem i stand til selv å opprettholde den sosiale orden, en moderne «governmentalitet». Den norske sykefraværspolitikken blir en slik form for depolitisering av temaet. IA-avtalen er et godt eksempel på det. Men staten styrer fortsatt en del, mest ved det som på engelsk kalles «layering», sedimentering, dvs. at gamle regler består, men brukes på nye måter. For eksempel består regelen om full lønn under ett års sykmelding, men det stilles stadig sterkere krav om gradert sykmelding og om å si opp den jobben man ikke greier.

Forfatteren sammenlikner denne utviklingen med de svenske innskrenkningene i sykepengerettighetene og knytter forskjellene til styringsteorier. Den mest trolige forklaringen er den sterke norske korporativismen, vetoat de store foreningene har så sterk innflytelse over staten. Det er vel en pen måte å si at LO har hatt vetorett når det gjelder sykelønnsordningen. Jeg tror det er riktig. Grunnen er antakelig at LO har gått med på mange små reduksjoner i velferdsytelsene siden 1991, inklusive den store alderspensjonsreformen og mange svekkelser av uførepensjonen, så lenge sykelønnen er hellig.

Bjørgulf Claussen

Professor i trygdemedisin, Universitetet i Oslo

\section{Oppklarende om bevisstheten}

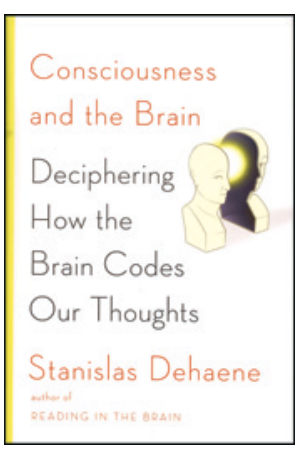

\author{
Stanislas Dehaene
}

Consciousness and the brain

Deciphering how the brain codes our

thoughts. 336 s, ill. New York, NY: Viking

Penguin, 2014. Pris USD 28

ISBN 978-0-670-02543-5

Bevisstheten er et fascinerende fenomen, og i epileptologien en daglig klinisk utfordring. I en rikholdig samling nye bøker om temaet står denne i en særklasse. Dehaene har basert boken på egen empirisk forskning på normalpersoner og nevropsykiatriske pasienter, inkludert personer med epilepsi som er undersøkt med implanterte elektroder i hjernen.

Forfatteren starter med noen historiske betraktninger, tar for seg bevissthetsforskning i laboratoriesetting og beskriver i detalj egen persepsjonsforskning på mennesker. Vi får innsikt i hva bevisstheten er god for, og lærer om bevissthetens signaturer. Vi får lese om undersøkelser med dybdeelektroder som registrerer på enkeltcellenivå, og teorier om bevisstheten i et bredere nevrobiologisk perspektiv, og vi får tanker om fremtidig forskning.

Her diskuteres «correlates» og «signatures of consciousness». Vi møter P3, «global ignition» med signalspredning til frontalog parietallappen, økning av aktivitet i gammabåndspekteret og massiv synkronisering av signaler i cortex som analyseres med «Granger causality analysis» med hensyn til både «bottom-up» og «top down» signaloverføring. Og mye, mye mer, inkludert litt om sykdom og klinikk.

Sentralt står teorien om «Global neuronal workspace», som er et slags korrelat for bevisstheten. Dehaene viser til at forskningen per i dag gir oss kausalitet. Men forfatteren er en utdannet matematiker i tillegg til å være psykolog, så han er av den oppfatning at kun matematisk teori kan forklare hvordan mental aktivitet «reduseres» til nevronal aktivitet.

Denne boken er definitivt den beste undertegnede har lest om temaet. Den er lett å lese og har 35 gode illustrasjoner. Dehaene er ingen filosof som dveler ved «qualia», de subjektive opplevelser, som for eksempel fru Olsens opplevelse av rødheten av rødt!

Her går man hypoteserettet til verks og kartlegger nevrobiologi i en klar og forståelig ramme, og skaper ny erkjennelse. Selvsagt vil noen spørsmål forbli ubesvart, inkludert selvbevissthet, og flere av forfatterens tolkninger er teorier. Jeg savner litt om epilepsi og bevissthet, og i kapitlet The Ultimate Test, om klinikk, grenser tankene rundt dyp hjernestimulering ved vegetative tilstander mot tunge etiske vurderinger.

Men alt i alt er det oppklarende innsikt som formidles. Dessuten viser Dehaene til betydningen av det ubevisste for våre valg og hjernefunksjoner. Han samler språk, langtidshukommelse, oppmerksomhet, persepsjon, motorikk og intensjonelle systemer i sin arbeidshypotese.

Boken burde være av interesse for alle nevrologer, nevropsykologer og psykiatere, og den anbefales varmt for alle som lurer på hvorledes bevisstheten hjelper oss i kommunikasjon og kognisjon.

Bernt A. Engelsen

Overlege, Epilepsienheten

Nevrologisk avdeling

Haukeland universitetssykehus 